九州大学学術情報リポジトリ

Kyushu University Institutional Repository

Contents of Cations and Anions and

Characterization of Stem Cell Wall Structures

on Stem of Red Pepper Plants Infected by

Phytophthora capsici

Lim, Youjin

College of Agriculture and Life science, Chungnam National University

Lee, Kyosuk

College of Agriculture and Life science, Chungnam National University

Lee, Dongsung

College of Agriculture and Life science, Chungnam National University

Cho, Jin-Woong

College of Agriculture and Life science, Chungnam National University

他

https://doi.org/10.5109/1564075

出版情報: 九州大学大学院農学研究院紀要. 61 (1)，pp.23-28，2016-02-29. Faculty of Agriculture， Kyushu University

バージョン :

権利関係 : 


\title{
Contents of Cations and Anions and Characterization of Stem Cell Wall Structures on Stem of Red Pepper Plants Infected by Phytophthora capsici
}

\author{
Youjin LIM ${ }^{1}$, Kyosuk LEE ${ }^{1}$, Dongsung $\mathrm{LEE}^{1}$, Jin-Woong $\mathrm{CHO}^{1}$, \\ Takeo YAMAKAWA* and Dougyoung CHUNG ${ }^{1 *}$
}

\author{
Laboratory of Plant Nutrition, Division of Molecular Biosciences, Department of Biosciences \& Biotechnology, \\ Faculty of Agriculture, Kyushu University,6-10-1 Hakozaki, Fukuoka 812-8581, Japan \\ (Received November 9, 2015 and accepted November 19, 2015)
}

\begin{abstract}
Pepper blight in red pepper plants is a lethal disease by the oomycete Phytophthora capsici that secrets cell wall degrading enzymes and polygalacturonase (PGs) that are hydrolase catalyzing the hydrolysis of pectin. In this experiment we conducted to observe contents of cations and anions and changes of cell wall structures of the stems of the infected red pepper plants by $P$. capsici. To do this, we inoculated zoospores of $P$. capsici using syringe with $21 \mathrm{G}$ needle on peeled stem of the red pepper plants. Stem cell wall structures of normal and infected pepper plants were identified by using optical microscope. Also protein contents and PGs activities by P. capsici and cations and anions of the stems of the normal and infected red pepper plants were measured. The results showed that any hyphae of $P$. capsici and destructed cell wall structures were not found in the normal plants while some hyphae of $P$. capsici and destroyed cell walls were found in the pepper plants showing symptoms of pepper blight. However, the hyphae of $P$. capsici were found but broken cell walls were not found in the red pepper plants that did not show any symptoms of pepper blight. The cations from normal and infected plants were in the same order of $\mathrm{K}>\mathrm{Ca}>\mathrm{Mg}$ $\approx \mathrm{Na}>\mathrm{Al}>\mathrm{Fe}$. K, Ca, and $\mathrm{Mg}$ were much higher than those of normal red pepper plants. However, Ca was approximately twice as much as of that of normal ones. Anions from normal and infected plants were in the same order of $\mathrm{Cl}^{-}>\mathrm{NO}_{3}^{-}>\mathrm{PO}_{4}^{3-}>\mathrm{SO}_{4}{ }^{2-}$. But $\mathrm{NO}_{3}^{-}-\mathrm{N}$ and $\mathrm{SO}_{4}{ }^{2-}-\mathrm{S}$ from the infected plants were almost 7.3 and 1.75 times of those from normal ones. Therefore, we assumed that $\mathrm{K}, \mathrm{Ca}, \mathrm{NO}_{3}^{-}$and $\mathrm{SO}_{4}{ }^{2-}$ could cause pepper blight on the red pepper plants.
\end{abstract}

Key words: Anions and cations, Phytophthora capsici, Red pepper, Stem cell wall structure

\section{INTRODUCTION}

The pathogen, Phytophthora capsici that kills seedlings and causes root rot, stem canker, leaf blight, and fruit rot in older plants, has a broad host range attacking tomato, eggplant, cucumber, watermelon, pumpkin, macadamia, and peppers (Kreutzer et al.,1940; Kunimoto, et al., 1976; Leonian, 1922; Polach and Webster, 1972; Ristaino, 1990). Stem infection near to the soil surface is known to be common and affected plants show sudden wilting and death (Sherf, 1986).

Many fungi and bacteria secrete remarkable arrays of plant cell wall-degrading enzymes during interactions with plants, among which are polygalacturonase (PGs), pectin methylesterases, pectate lyases, and cellulases (Collmer and Keen, 1986). However, the fungi in soil and on infected seeds are difficult to control because of its wide host range and its ability to survive in the soil although there are many measures to control phytophthora blight such as avoiding fields with a history of the disease, planting in well-drained soils, and the application of fungicides (Zitter, 2006).

P. capsici is pepper blight pathogen that belongs to oomycete known as water mold swimming through water in the soil. Zoospores of P. capsici encyst the root sur-

College of Agriculture and Life science, Chungnam National University, Daejeon, 305-764, Korea

* Joint Corresponding author (E-mail: yamakawa@kyushu-u. ac.jp)

* Joint Corresponding author (E-mail: dychung@cnu.ac.kr) face by recognition of the exudates released by the roots of potential host plants (Hinch and Clarke, 1980; EstradaGarcia et al., 1990; Jones et al., 1975, 1991), adherence to the root surface by exocytosis of a proteinaceous material (Gubler et al., 1989; Hardham, 1992), and germination by hyphal outgrowth from a predetermined site located next to the host (Mitchell and Deacon, 1986; Hardham, 1992), and direct penetration of the hypha into the host or after producing an appressorium (Bircher and Hohl, 1997). These sequences are extremely rapid, leading to infection within 30-40 min of the zoospore arriving at a host surface (Deacon and Donaldson, 1986).

$P$. capsici secretes enzymes that can degrade the polysaccharides of plant cell walls (Albersheim and Anderson, 1971). The polysaccharide-rich cell wall, one of the barriers against pathogenic fungi invasion, can be degraded by a number of hydrolytic enzymes capable of degrading cell wall polymers (Salama et al., 2008). PG degrades polygalacturonan present in the cell walls of plants by hydrolysis of the glycosidic bonds that link galacturonic acid residues found in the cell walls and middle lamella of plants (De Lorenzo and Ferrari. 2002).

However, plants exposed to a wide array of phytopathogenic fungi counteract fungal invasion through a series of preexisting and/or induced defense mechanisms. The PG-inhibiting proteins (PGIPs) present in the cell wall of many plants have the capability of limiting fungal colonization by slowing the hydrolytic activity of PGs and favor the accumulation of oligogalacturonides, which 
are elicitors of a variety of defense responses (De Lorenzo and Ferrari, 2002). However, polymerization mechanism between PGIP and PG is precisely not only unsolved but also the mechanism of initial infection for cell walls by $P$. capsici producing PG is not clearly identified.

In this article, we tried to verify influencing factors of pepper blight disease by $P$. capsici by investigating the ionic species and their contents and morphological changes of stem cells in the red pepper plants which were infected by $P$. capsici and not infected. The results of this research may help to develop alternative control methods for the reduction of the incidence of Phytophthora blight of pepper.

\section{MATERIALS AND METHODS}

\section{Plant materials and fungal cultures}

Red pepper plants (Capsicum annum L.), grown in a plastic tray packed with growth media mixed with soil in a growth chamber at $30 \pm 2^{\circ} \mathrm{C}$ and $50-70 \%$ relative humidity, with $12 \mathrm{~h}$ day $^{-1}$ white fluorescent light $(192 \mu \mathrm{mol}$ $\mathrm{s}^{-1} \mathrm{~m}^{-2}$ ) for six weeks after germination, were inoculated with $P$. capsici causing pepper blight obtained from Korean Collection for Type Culture (KCTC) located in Daejeon Korea and was cultured for 5 days at $27^{\circ} \mathrm{C}$ in a potato dextrose agar(PDA) medium (Eddleman, 1999). However, $50 \mathrm{~mL}$ of deionized water were applied on the surface of each pot of a growth media tray every other days using a spray bottle while $10 \mathrm{~mL}$ of nutrient solution $\left(10 \mathrm{~g} \mathrm{~L}^{-1}\right)$ made of composite fertilizer $(\mathrm{N}-\mathrm{P}-\mathrm{K}=$ 21-17-17) were applied on the surface of each pot every seven days during the investigation period. Forty discs of $P$. capsici were shaken and cultured for 12 days at $20^{\circ} \mathrm{C}$ (Carver et al., 1994) to verify the presence of PG in the PDA medium. After spores of pathogen were inoculated on the peeled area of stem near to soil surface for the 100 healthy red peppers using syringe with 21 G needle, red pepper plants showing pepper blight disease were also selected to investigate the ion contents and the cell structure of the red pepper plant with the pepper blight disease along with control plants.

\section{Incidence rates of pepper blight disease}

Incidence rates of pepper blight disease among the 100 red pepper plants inoculated with $P$. capsici were measured by counting number of the samples by observing the symptoms as the form of water-soaking lesions on the stems of the red pepper plants until no symptoms of the pepper blight disease from the red pepper plants were observed during 30 days.

\section{Assay of PG activity}

The assay of PG activity was conducted with the red pepper plants inoculated with $P$. capsici during 30days. To do this, the 5-cm long stem sections of the red pepper plants with and without the symptoms of the pepper blight disease depending on the sampling date were cut and homogenized with a Brinkmann Polytron PT 3000 in $3 \mathrm{vol}$ of $1.3 \mathrm{M} \mathrm{NaCl} / 0.05 \mathrm{M}$ sodium phosphate, $\mathrm{pH}$ 6.0/40 mM 2-mercaptoethanol. The supernatant was recovered after centrifugation $(11,000 \times \mathrm{g}, 30 \mathrm{~min})$. The reaction mixture consisted of $100 \mu \mathrm{L}$ of $0.4 \%$ polygalacturonic acid in $100 \mathrm{mM}$ sodium acetate (pH 5.5) and $100 \mu \mathrm{L}$ of enzyme solution. The reaction mixture was incubated for $1 \mathrm{~h}$ at $55^{\circ} \mathrm{C}$, and then the reaction was terminated by addition

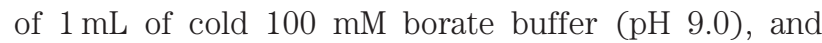

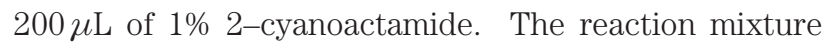
was incubated in a boiling water bath for $10 \mathrm{~min}$. The PG activities for the homogenized red pepper plants were assayed by estimating the amount of reducing groups released from sodium polypectate, using D-galacturonic acid as standard to establish the calibration curve obtained by the change in absorbance at $279 \mathrm{~nm}$ after cooling. One unit of PG activity was defined as the amount of galacturonic acid required to release $1 \mu \mathrm{mol}$ of reducing groups per minute at $37^{\circ} \mathrm{C}$ in a mixture containing $0.176 \%$ sodium polypectate and $80 \mathrm{mM}$ sodium acetate ( $\mathrm{pH}$ 5.0).

\section{Protein contents and gel electrophoresis}

The proteins contained in the cell walls of the red pepper plants have been known to inhibit the fungal endo PGs (De Lorenzo et al., 2001). To verify change in the protein content for the red pepper plants inoculated with $P$. capsici during 30 days experimental period, the protein contents of the red pepper plants were determined by the method of Bradford (1976) using a BioRad protein assay kit with bovine serum albumin (BSA) as standard by recording the absorbance of protein solutions at $595 \mathrm{~nm}$ in a Optizen $3220 \mathrm{UV}$. The linear relationship between the absorbance and known protein concentration was then used to determine the relative protein concentrations of the samples.

The purified enzyme was subjected to electrophoretic studies to determine molecular weight. The sodium dodecyl sulfate polyacrylamide gel electrophoresis (SDSPAGE) with a 5\%(w/v) stacking gel and a 10\%(w/v) separating gel was performed to separate proteins with relative molecular mass according to the method of Laemmli (1970) known as the discontinuous electrophoresis method. The range of pre-stained protein molecular weight marker (Bio-Rad Laboratories) used as the standards was from $35 \mathrm{kDa}$ to $245 \mathrm{kDa}$ for molecular weight determination of proteins. Gels were stained for 1 to 3 hours in a solution of Coomassie Blue R-250, 45\% methanol and 9\% acetic acid. Electrophoresis was carried out with the energy source in the constant current mode of $5 \mathrm{~mA}$ per gel and the mobility was measured as the distance traveled by the protein band in centimeters.

\section{Optical microscope for cell structure}

The approx. $30 \mu \mathrm{m}$ thick samples were prepared by microtome from segments of the stems showing symptom of $P$. capsici infection. For the transverse sections of the red pepper plants, pictures of stem cell structure were taken using optical microscope LEICA DM 750.

\section{Cations and anions on the stems of the red pepper plants}

For analysis of cations and anions on the stems of the 
infected and the uninfected red pepper plants, $0.5 \mathrm{~g}$ of the oven-dried and ground pepper plant materials was added in the digestion tube with $10 \mathrm{ml}$ concentrated nitric acid (70\%) and the temperature was carefully heated to $200^{\circ} \mathrm{C}$ on Kjeldahl block digester, followed by addition of $8 \mathrm{ml}$ perchloric acid (70\%). Additions were continued until the clearing stage was completed when the digest became permanently discolored and white acid fumes appeared. The cooled solutions were then made $100 \mathrm{ml}$ volume with distilled water. After through mixing, a portion of the solution was poured into a $60-\mathrm{ml}$ Nalgene bottle for analysis of cations using by ICP-OES (Agilent Technology 720, USA) while anions in a solution was measured by ion chromatography (Dionex DX-500, USA).

\section{RESULTS AND DISCUSSION}

\section{Incidence rates of pepper blight disease on the red pepper plants}

The symptoms of pepper blight disease were appeared as the form of water-soaking lesions on the stems of the red pepper. The first incidence was observed at day 2 after inoculation of $P$. capsici and the greatest incidence rate was recorded as approximately 53\% for 100 plants on day 2 during 30 days experimental period. However, the incidence rate was rapidly decreased from $53 \%$ on day 2 to $0 \%$ after day 6 , indicating that the pepper blight disease was ceased. The cumulative incidence rate reached to $91 \%$ for 100 plants during 30 days experimental period, indicating that $9 \%$ of the plants inoculated with $P$. capsici did not show any infection symptoms of pepper blight disease (Fig. 1).

\section{PG activity and protein contents}

The production of PGs showed that PG activities on extract were gradually increased from $0.27 \mathrm{U}$ on day 0 to $3.23 \mathrm{U}$ on day 12 as the highest content and then rapidly decreased to $0.42 \mathrm{U}$ on day 30 during the 30 days of the experimental period (Fig. 2). The PG activity was

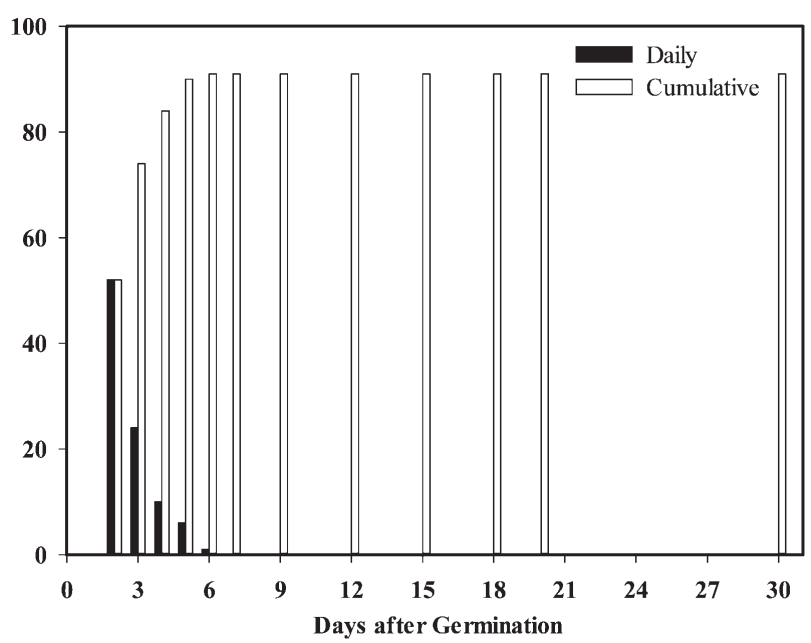

Fig. 1. Cumulative and daily incidences of pepper blight disease for the red pepper plants after treatment of $P$. capsici. Incidence rates were calculated as \% of diseased plants among the all treated 100 plants for 30 days.



Fig. 2. PG activities and protein content measured at the lesion areas of the stems of the red pepper plants inoculated with $P$. capsici for 30 days of the experimental period.

increased to day 12 and then rapidly decreased to on day 30 although the pepper blight disease was not observed after day 6 as seen in Fig. 1. The PG activity measured on day 6 which was the last day we could observe the pepper blight disease among the 100 red pepper plants inoculated with $P$. capsici was $1.88 \mathrm{U}$ which was lower than the highest PG activity measured on day 12 that we could not observe any symptom of the pepper blight disease among the inoculated red pepper plants. From this result, we could assume that the incidence of the pepper blight disease influenced by PGs of $P$. capsici was also influenced by polygalacturonase inhibiting proteins (PGIPs) as reported by Yao et al. (1995) and Oelofse et al. (2006).

The PG protein contents measured from the same homogenized samples used for assay of PG activity showed an almost similar result as seen in Fig. 2. As shown in Fig. 2, the content of protein was increased with increasing $\mathrm{PG}$ activity and decreased with decreasing $\mathrm{PG}$ activity. The ratio obtained from the calculation of $\mathrm{PG}$ activity vs. protein content as shown in Fig. 2 showed that the ratio was rapidly decreased with increasing $P G$ activity for the first 12 days after inoculation while the ratio was slightly increased with decreasing PG activity after 12 days during 30 days of the experimental period. Compared with the incidence rate of the pepper blight disease, the ratio was also decreased with decreasing incidence rate. From this comparison, we could assume that the increasing PG activity did not closely correlated with the pepper blight disease for the red pepper plants in this experiment. Also, we could assume that the incidence of the pepper blight disease influenced by PGs of $P$. capsici was also influenced by polygalacturonase inhibiting proteins (PGIPs) as reported by Yao et al. (1995) and Oelofse et al. (2006).

When proteins are separated in the presence of SDSPAGE and denaturing agents, they become fully denatured and dissociate from each other. The purified PG was electrophoretically homogenous as judged by electrophoresis gel (Fig. 3), where one protein band on SDS-PAGE was detected. According to the comparison 




Fig. 3. Proteins separated on SDS-PAGE and detected by Coomassie blue 250. The bands in a red box indicate PG proteins. Lane M : Molecular weight marker; Lanes 1-3: the crude extracts of the infected red pepper. The PG protein from the crude extracts of the red peppers showed a molecular weight of $63 \mathrm{kDa}$.

with molecular weight protein standards, SDS-PAGE analysis showed that the molecular weight of protein measured in this experiment dominantly reveled $63 \mathrm{kDa}$ band, in agreement with the predicted molecular weight for the target protein PG (Fig. 3).

\section{Stem cell structures of the red pepper plant.}

Micrographs of the stem cell structures of control (not inoculated) and the pepper plants inoculated with $P$. capsici were observed by an optical microscope as illustrated in Fig. 4. The cell structures observed from control and the infected plants at day 6 after inoculation showed that hyphae of $P$. capsici and destructed cell wall structures were not found in the control plants while hyphae of P.capsici and destroyed cell walls were found in the pepper plants showing symptoms of pepper blight disease. However, hyphae of $P$. capsici are found but broken cell walls are not found in 9 red pepper plants that did not show any symptoms of pepper blight disease 6 days after inoculation (Fig. 4). In general, infecting hyphae grew in the intercellular space between xylem vessels of the stem tissues, and membrane structures were disorganized as shown in Fig. 4. An intercellular hypha in irregular and indistinct structures was observed in the plasmolyzed host cell (Fig. 4C). Some vacuolated and distorted hyphae were shown to grow compactly in the intercellular spaces surrounded by the host cell walls (Fig. 4D). The invading haustorium in intimate contact with host cytoplasmic materials (Fig. 4E). However, no distinct host responses such as wall appositions were found in the control plant without inoculation of $P$. capsici (Fig. 4F).

\section{Ion contents in the stems of the red pepper plants}

Generally, most of the studies regarding to pepper blight disease for the red pepper plants focused on the cell wall degrading enzymes as virulence factors and their infection mechanisms. The researches related to the nutritional aspects on the infected plants by $P$. capsici have rarely been done. Therefore, we measured contents and major ionic species of cations and anions on the stem areas of the normal and the infected red pepper plants. The amounts of cations recovered from both normal and infected plants were in the same order of $\mathrm{K}>$ $\mathrm{Ca}>\mathrm{Mg} \approx \mathrm{Na}>\mathrm{Al}>\mathrm{Fe}$. The amount of cations of the stems of the infected red pepper plants were 401, 40.8, 26.2, 26.6, 1.8 and $1.3 \mathrm{mg} \mathrm{kg}^{-1}$ for $\mathrm{K}, \mathrm{Ca}, \mathrm{Mg}, \mathrm{Na}, \mathrm{Al}$, and $\mathrm{Fe}$, respectively. Among these cations, the amounts of $\mathrm{K}$, $\mathrm{Ca}$, and $\mathrm{Mg}$ were much higher than those of normal red pepper plants while the amounts of $\mathrm{Na}, \mathrm{Al}$, and $\mathrm{Fe}$ recovered from the infected plants were slightly higher or simi-
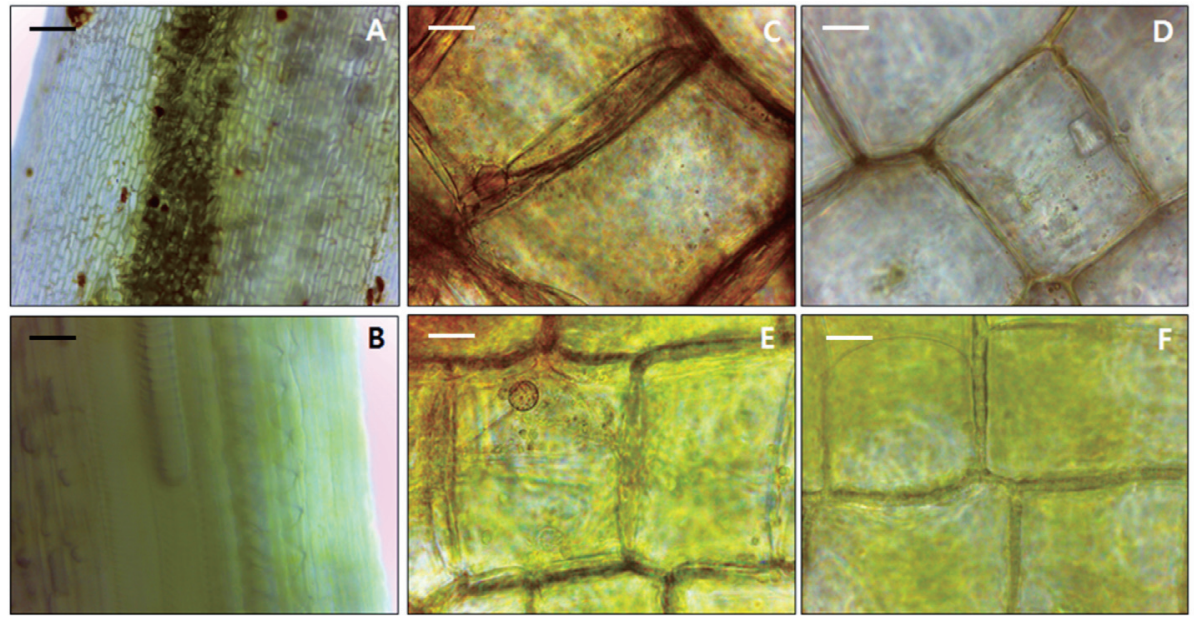

Fig. 4. Pictures of stem surfaces and stem cell structure of the pepper plants. (A) A stem surface infected by P. capsici. (B) A stem surface of normal pepper plant. (C) An infected stem cell structure showing an intercellular hypha in irregular and indistinct structures. (D) A hypha compactly growing in the intercellular space surrounded by the host cell walls. (E) A haustorium surrounded by host plasma membrane in the red pepper plant inoculated with $P$. capsici. But it did not show any symptom of pepper blight disease on the stem of the pepper plant. (F) Control plant without inoculation. Black scale bar $=1 \mu \mathrm{m}$, white scale bar $=10 \mu \mathrm{m}$. 
Table 1. Cation contents on the stems of the uninfected and the infected red pepper plants inoculated with $P$. capsici showing the form of water-soaking lesions

\begin{tabular}{ccccccc}
\hline \multirow{2}{*}{ Sample } & \multicolumn{7}{c}{ Content of cation $\left(\mathrm{mg} \mathrm{kg}^{-1}\right)$} \\
\cline { 2 - 7 } & $\mathrm{K}$ & $\mathrm{Ca}$ & $\mathrm{Mg}$ & $\mathrm{Na}$ & $\mathrm{Al}$ & $\mathrm{Fe}$ \\
\hline \multirow{2}{*}{ Infected } & $401 \pm 18$ & $40.8 \pm 1.0$ & $26.2 \pm 3.9$ & $26.6 \pm 0.1$ & $1.8 \pm 0.2$ & $1.3 \pm 0.3$ \\
Uninfected & $325 \pm 0.5$ & $24.8 \pm 0.5$ & $19.0 \pm 0.7$ & $23.2 \pm 1.1$ & $1.1 \pm 0.4$ & $0.9 \pm 0.1$ \\
\hline
\end{tabular}

The figure in table indicate average \pm standard deviation (n-3).

Table 2. Anion contents on the stems of the uninfected and the infected red pepper

\begin{tabular}{ccccc}
\hline \multirow{2}{*}{ Sample } & \multicolumn{4}{c}{ Content of anion $\left(\mathrm{mg} \mathrm{kg}^{-1}\right)$} \\
\cline { 2 - 5 } & $\mathrm{Cl}^{-}$ & $\mathrm{NO}_{3}{ }^{-}-\mathrm{N}$ & $\mathrm{PO}_{4}{ }^{3-}-\mathrm{P}$ & $\mathrm{SO}_{4}{ }^{2-}-\mathrm{S}^{2}$ \\
\hline Infected & $8556 \pm 28$ & $5306 \pm 538$ & $720 \pm 24.1$ & $3573 \pm 2.4$ \\
Uninfected & $8822 \pm 55$ & $730 \pm 1.5$ & $760 \pm 10.0$ & $2077 \pm 9.3$ \\
\hline
\end{tabular}

Stems inoculated with $P$. capsici showing the form of water-soaking lesions.

The figure in table indicate average \pm standard deviation (n-3).

lar to those of the normal plants. However, the amount of Ca was approximately twice as much as of that of normal one (Table 1). The both plants of normal and infected ones, the amounts of cations of both the normal and the infected plants were in the same order of $\mathrm{Cl}^{-}>$ $\mathrm{NO}_{3}^{-}>\mathrm{PO}_{4}{ }^{3-}>\mathrm{SO}_{4}{ }^{2-}$. Compared with the amounts of anions between these two treatments for the red pepper plants, the results showed that the amount of $\mathrm{NO}_{3}^{-}-\mathrm{N}$ and $\mathrm{SO}_{4}^{2-}-\mathrm{S}$ from the infected plants were almost 7.3 and 1.75 times of those from normal one whereas the amounts of $\mathrm{Cl}^{-}$and $\mathrm{PO}_{4}^{3-}-\mathrm{P}$ on the stems of the infected plants were very similar to those on the normal ones (Table 2). From these results of cations and anions of these normal and infected plants, we could assume that cations of $\mathrm{K}$ and $\mathrm{Ca}$ and anions of $\mathrm{NO}_{3}^{-}$and $\mathrm{SO}_{4}{ }^{2-}$ could be the factor to cause pepper blight disease on the red pepper plants.

\section{CONCLUSIONS}

Many previous studies have shown that plant pathogens must breach cell walls before they can infect the hosts by secreting an array of pectinases during plantpathogen interaction. In this study, we found that more than $50 \%$ of incidence as of the pepper blight disease were occurred within two days after inoculation with $P$. capsici. The retarded incidence rate of pepper blight disease until day 6 could be influenced by growth of invading hyphae and penetration into cell layers as observed by Jones et al. (1975). The maximum production of PG as $63 \mathrm{kDa}$ band and PG activities on extract were 43.6 $\mathrm{mg} \mathrm{L}^{-1}$ and $3.23 \mathrm{U}$ on day 12 , respectively while the incidence of pepper blight disease were ceased on day 6 after inoculation of $P$. capsici. From this results, we could find out that the amount of PG and its activities could not be a major factor on the incidence of pepper blight disease on the red pepper plants. The results of the cell wall structures on the stems of the red pepper plants showed that hyphae of $P$. capsici and destructed cell wall structures were not found in the control plants while hyphae of $P$. capsici and destroyed cell walls were found in the pepper plants showing symptoms of pepper blight disease. However, hyphae of $P$. capsici are found but broken cell walls are not found in 9 red pepper plants that did not show any symptoms of pepper blight disease on 6 days after inoculation. From this result, we could said that the presence of $P$. capsici inside the broken cell wall could not lead to pepper blight disease for the red pepper plants. The amounts of cation and anions on the lesion of the stem could be one of the inducing factors for the pepper blight disease for the red pepper plants. Especially $\mathrm{Ca}$ and $\mathrm{NO}_{3}{ }^{-}$could attribute to cause pepper blight disease. However, we need further investigation for influence of nutritional sources such as $\mathrm{Ca}, \mathrm{NO}_{3}^{-}$, and $\mathrm{SO}_{4}^{2-}$ on the incidence of pepper blight disease for red pepper plants.

\section{ACKNOWLEDGMENT}

This study was carried out with the support of "Research Program for Agricultural Science \& Technology Development (Project No. PJ009302012013)", National Academy of Agricultural Science, Rural Development Administration, Republic of Korea.

\section{REFERENCES}

Albersheim, P. and A. J. Anderson 1971 Proteins from plant cell walls inhibit polygalacturonases secreted by plant pathogens. Proc. Natl. Acad. Sci. 68: 1815-1819

Bircher, A. and H. R. Hohl 1997 Environmental signaling during induction of appressorium formation in Phytophthora. Mycol. Res. 1014: 395-402

Bradford, M. M. 1976 A rapid and sensitive method for the quantitation of microgram quantities of protein utilizing the principle of protein-dye binding. Anal. Biochem. 72: 248-254

Carver, L. A., V. Jackiw and C. A. Bradfield 1994 The 90-kDa heat shock protein is essential for Ah receptor signaling in a yeast expression system. J. Biol Chem. 272: 11452-11456

Collmer, A. and N. T. Keen 1986 The role of pectic enzymes in plant pathogenesis. Annu. Rev. Phytopathol. 24: 383-409 
De Lorenzo, G., R. D'Ovidio and F. Cervone 2001 The role of polygalacturonase-inhibiting proteins (PGIPs) in defence against pathogenic fungi. Annu. Rev. Phytopathol. 39: 313-335

De Lorenzo, G. and S. Ferrari 2002 Polygalacturonase-inhibiting proteins in defense against phytopathogenic fungi. Curr. Opin. Plant Biol. 5: 295-299

Deacon, J. W. and S. P. Donaldson 1986 Molecular recognition in the homing responses of zoosporic fungi, with special reference to Pythium and Phytophthora. Mycol. Res. 97: 11531171

Eddleman, H. 1999 Ingredients used in Microbiological Media. http://www.disknet.com/indiana_biolab/b041.htm

Estrada, G. T., T. C. Ray, J. R. Green, J. A. Callow and J. F. Kennedy 1990 Encystment of Pythium aphanidermatum zoospores induced by root mucilage polysaccharides, pectin and a monoclonal antibody to a surface antigen. J. Exp. Bot. 41: 693-699

Gubler, F. and A. R. Hardham 1990 Protein storage in large peripheral vesicles in Phytophthora zoospores and its breakdown after cyst germination. Exp. Myco. 14: 393-404

Hardham, A. R. 1992 Cell biology of pathogenesis. Ann. Rev. Plant Phys. 43: 491-526

Hinch, J. M. and A. E. Clarke 1980 A method for the production of ${ }^{14} \mathrm{C}$-labeled Phytophthora cinnamomi zoospores. Exp. Mycol. 6: $60-64$

Jones, D. R., W. G. Graham and E. W. B. Ward 1975 Ultrastructural changes in pepper eels in an incompatible interaction with Phytophthora infestans. Phytopathology 65: $1274-1279$

Jones, S. W., S. P. Donalson and J. W. Deacon 1991 Behaviour of zoospores and zoospore cysts in relation to root infection by Pythium aphanidermatum. New Phytol. 117: 289-301

Kreutzer, W. A., E. W. Bodine and L. W. Durrell 1940 Cucurbit diseases and rot of Tomato fruit caused by Phytophthora capsici. Phytopathology 30: 972-975

Kunimoto, R. K., M. Aragaki, J. E. Hunter and W. H. Ko 1976 Phytophthora capsici, corrected name for the cause of
Phytophthora blight of Macadamia racemes. Pathology 5 546-548

Laemmli, U. K. 1970 Cleavage of structural proteins during the assembly of the head of bacteriophage T4. Nature 227: 680685

Leonian, L. H. 1922 Stem and fruit blight of Peppers caused by Phytophthora capsici sp. nov. Phytopathology 12: 401-408

Mitchell, R. T. and J. W. Deacon 1986 Differential (hostspecific) accumulation of zoospores of Pythium on roots of graminaceous and non-graminaceous plants. New Phytol. 102: 113122

Oelofsea, D., I. A. Duberyb, R. Meyerb, M. S. Arendsea, I. Gazendama and D. K. Bergerc 2006 Apple polygalacturonase inhibiting protein 1 expressed in transgenic tobacco inhibits polygalacturonases from fungal pathogens of apple and the anthracnose pathogen of lupins. Phytochemistry 67: 255263

Polach, F. J. and R. K. Webster 1972 Identification of strains and inheritance of pathogenicity in Phytophthora capsici. Phytopathology 62: 20-26

Ristaino, J. B. 1990 Intraspecific variation among isolates of Phytophthora capsici from pepper and cucurbit. Phytopathology 80: 1253-1259

Salama A. O., I. A. Mohamed and A. E. Ibrahem 2008 In Vitro evaluation of the biocontrol activity of some biofungicides on Sclerotium Cepivorum. Int. J. Agri. Biol. 10: 241-248

Sherf, A. F. 1986 Vegetable diseases and their control. John Willey \& Sons p. 728

Yao, C. L., W. S. Conway and C. E. Sams 1995 Purification and characterization of a polygalacturonase-inhibiting protein from apple fruit. Phytopathology 85: 1373-1377

Zitter, T. A. 2006 Disease update the long list of diseases affecting tomatoes and peppers in a wet growing season. http://vegetablemdonline.ppath.cornell.edu/NewsArticles/Wet Season /Dis ease\%20-\%20Tomato1.pdf 